\title{
Theoretical and Experimental Studies of the
}

\section{Photoluminescent Properties of the Coordination}

\author{
Polymer [Eu(DPA)(HDPA)( $\left.\left.\mathrm{H}_{2} \mathrm{O}\right)_{2}\right] \cdot 4 \mathrm{H}_{2} \mathrm{O}$.
}

\section{Supporting Information}

Marcelo O. Rodrigues ${ }^{1}$, Nivan B. Costa Júnior ${ }^{2}$, Carlos A. de Simone ${ }^{3}$, Adriano A. S. Araújo ${ }^{2}$,

A. M. Brito-Silva ${ }^{4}$, Filipe A. Almeida Paz ${ }^{5}$, Maria E. de Mesquita ${ }^{2}$; Severino A. Júnior ${ }^{1}$ and

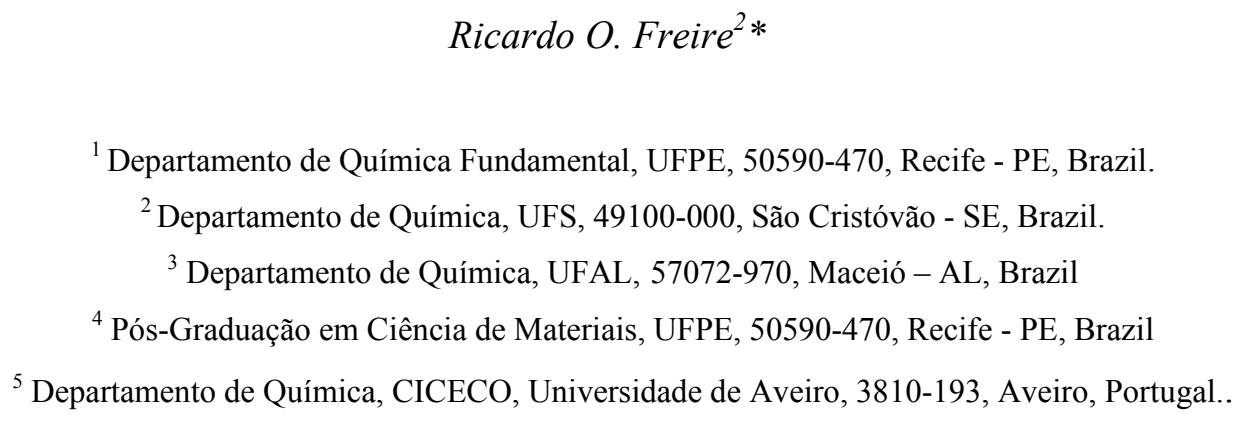

Author email address: mzohio@hotmail.com (Marcelo O. Rodrigues);

salvesjr@ufpe.br (Severino Alves Júnior)

rfreire@ufs.br (Ricardo O. Freire) 


\section{Single-Crystal X-ray Diffraction (crystallographic characterization of the compound)}

A suitable single-crystal of $\left[\mathrm{Eu}(\mathrm{DPA})(\mathrm{HDPA})\left(\mathrm{H}_{2} \mathrm{O}\right)_{2}\right] \cdot 4 \mathrm{H}_{2} \mathrm{O}$ (where $\mathrm{H}_{2}$ DPA stands for pyridine-2,6-dicarboxylic acid) was manually harvested from the crystallization vial and mounted on a glass fibre. ${ }^{(1)}$ Data were collected at ambient temperature on a Nonius Kappa charge-coupled device (CCD) area-detector diffractometer $\left(\mathrm{Mo} \mathrm{K}_{\alpha}\right.$ graphite-monochromated radiation, $\lambda=0.7107 \AA$ ) controlled by the Collect software package. ${ }^{(1)}$ Images were processed using the software packages Denzo and Scalepack, ${ }^{(3)}$ and data were corrected for absorption by the empirical method implemented in SADABS. ${ }^{(4)}$ The structure was solved using the direct methods implemented in SHELXS-97, ${ }^{(5)}$ which allowed the immediate location of the majority of the heavy atoms. All the remaining non-hydrogen atoms were directly located from difference Fourier maps calculated from successive full-matrix least squares refinement cycles on $F^{2}$ using SHELXL-97. ${ }^{(6)}$ All non-hydrogen atoms were successfully refined using anisotropic displacement parameters.

Hydrogen atoms associated with all water molecules (both coordinated and housed within the channels present in the structure) were directly located from difference Fourier maps, and included in the final structural model with the $\mathrm{O}-\mathrm{H}$ and $\mathrm{H} \cdots \mathrm{H}$ distances restrained to $0.95(1) \AA$ and $1.55(1) \AA$, respectively (in order to ensure a chemically reasonable geometry for these molecules), and using a riding model with an isotropic displacement parameter fixed at 1.5 times $U_{e q}$ of the atom to which they are attached. Even though an approximate position for the hydrogen atom of the protonated carboxylic acid group of HDPA- could also be determined from determined from difference Fourier maps, the atomic parameters for this atom were instead restrained to produce the final structural model by using the HFIX 147 instruction in SHELXL. Hydrogen atoms attached to carbon were located at their idealized positions by employing the HFIX 43 instructions in SHELXL, and included in subsequent refinement cycles in riding-motion approximation with isotropic thermal displacements parameters $\left(U_{\text {iso }}\right)$ fixed at 1.2 times $U_{e q}$ of the carbon atom to which they are attached.

The last difference Fourier map synthesis showed the highest peak $\left(1.291 \mathrm{e}^{-3}\right)$ and deepest hole $\left(-1.838 \mathrm{e}^{-3}\right)$ located at $0.91 \AA$ and $0.81 \AA$, respectively, from Eu.

Information concerning crystallographic data collection and structure refinement details is summarized in Table S1. Hydrogen bonding geometric details is given in Table S2. 
Table S1 - Crystal and Structure Refinement Data for [Eu(DPA)(HDPA) $\left.\left(\mathrm{H}_{2} \mathrm{O}\right)_{2}\right] \cdot 4 \mathrm{H}_{2} \mathrm{O}$.

\begin{tabular}{|c|c|}
\hline Formula & $\mathrm{C}_{14} \mathrm{H}_{19} \mathrm{EuN}_{2} \mathrm{O}_{14}$ \\
\hline Formula weight & 591.27 \\
\hline Crystal system & Monoclinic \\
\hline Space group & $P 2_{1} / \mathrm{a}$ \\
\hline$a / \AA$ & $12.8310(2)$ \\
\hline$b / \AA$ & $11.2170(4)$ \\
\hline$c / \AA$ & $13.9930(4)$ \\
\hline$\alpha /^{\circ}$ & 90 \\
\hline$\beta /^{\circ}$ & $102.474(2)$ \\
\hline$\gamma /{ }^{\circ}$ & 90 \\
\hline Volume $/ \AA^{3}$ & $1966.41(9)$ \\
\hline$Z$ & 4 \\
\hline$D_{c} / \mathrm{g} \mathrm{cm}^{-3}$ & 1.997 \\
\hline$\mu(\mathrm{Mo}-\mathrm{K} \alpha) / \mathrm{mm}^{-1}$ & 3.268 \\
\hline Crystal size/mm & $0.21 \times 0.16 \times 0.11$ \\
\hline$\theta$ range & 2.67 to 27.49 \\
\hline \multirow[t]{3}{*}{ Index ranges } & $-16 \leq h \leq 16$ \\
\hline & $-14 \leq k \leq 13$ \\
\hline & $-14 \leq l \leq 18$ \\
\hline Reflections collected & 14940 \\
\hline Independent reflections & $4467\left(R_{\mathrm{int}}=0.0432\right)$ \\
\hline Completeness to $\theta=27.49^{\circ}$ & $98.8 \%$ \\
\hline \multirow[t]{2}{*}{ Final $R$ indices $[\mathrm{I}>2 \sigma(\mathrm{I})]^{a, b}$} & $R 1=0.0271$ \\
\hline & $w R 2=0.0707$ \\
\hline \multirow[t]{2}{*}{ Final $R$ indices (all data) $)^{a, b}$} & $R 1=0.0293$ \\
\hline & $w R 2=0.0723$ \\
\hline \multirow[t]{2}{*}{ Weighting scheme ${ }^{c}$} & $m=0.0366$ \\
\hline & $n=2.4610$ \\
\hline Largest diff. peak and hole & 1.291 and $-1.838 \mathrm{e}^{-3}$ \\
\hline
\end{tabular}

The hydrothermal reaction between $\mathrm{Eu}_{2} \mathrm{O}_{3}$ and pyridine-2,6-dicarboxylic acid $\left(\mathrm{H}_{2} \mathrm{DPA}\right)$ led to the isolation of a large amount of a single-crystalline phase composed by crystals exhibiting a parallelepipedic morphology, whose structure was ultimately unveiled from single-crystal $\mathrm{X}$-ray diffraction studies at ambient temperature and formulated as $\left[\mathrm{Eu}(\mathrm{DPA})(\mathrm{HDPA})\left(\mathrm{H}_{2} \mathrm{O}\right)_{2}\right] \cdot 4 \mathrm{H}_{2} \mathrm{O}$ (Table 1). 
Table S2 - Hydrogen bonding geometry (distances in $\AA$ and angles in degrees) for $\left[\mathrm{Eu}(\mathrm{DPA})(\mathrm{HDPA})\left(\mathrm{H}_{2} \mathrm{O}\right)_{2}\right] \cdot 4 \mathrm{H}_{2} \mathrm{O} .^{a}$

\begin{tabular}{|c|c|c|}
\hline $\mathrm{D}-\mathrm{H} \cdots \mathrm{A}$ & $\mathrm{d}(\mathrm{D} \cdots \mathrm{A})$ & $<(\mathrm{DHA})$ \\
\hline $\mathrm{O}(2)-\mathrm{H}(2) \cdots \mathrm{O}(3 \mathrm{~W})$ & $2.478(4)$ & $175(1)$ \\
\hline $\mathrm{O}(1 \mathrm{~W})-\mathrm{H}(1 \mathrm{~A}) \cdots \mathrm{O}(4)^{\mathrm{i}}$ & $2.733(3)$ & $167(4)$ \\
\hline $\mathrm{O}(1 \mathrm{~W})-\mathrm{H}(1 \mathrm{~B}) \cdots \mathrm{O}(6)$ & $2.718(3)$ & $155(3)$ \\
\hline $\mathrm{O}(2 \mathrm{~W})-\mathrm{H}(2 \mathrm{~A}) \cdots \mathrm{O}(5 \mathrm{~W})^{\mathrm{ii}}$ & $2.723(3)$ & $161(3)$ \\
\hline $\mathrm{O}(2 \mathrm{~W})-\mathrm{H}(2 \mathrm{~B}) \cdots \mathrm{O}(6 \mathrm{~W})$ & $2.744(3)$ & $165(3)$ \\
\hline $\mathrm{O}(3 \mathrm{~W})-\mathrm{H}(3 \mathrm{~A}) \cdots \mathrm{O}(4)^{\mathrm{iii}}$ & $2.641(4)$ & $174(5)$ \\
\hline $\mathrm{O}(3 \mathrm{~W})-\mathrm{H}(3 \mathrm{~B}) \cdots \mathrm{O}(4 \mathrm{~W})^{\mathrm{iii}}$ & $2.799(5)$ & 143(4) \\
\hline $\mathrm{O}(4 \mathrm{~W})-\mathrm{H}(3 \mathrm{~B}) \cdots \mathrm{O}(3)$ & $2.950(4)$ & $157(5)$ \\
\hline $\mathrm{O}(5 \mathrm{~W})-\mathrm{H}(3 \mathrm{~B}) \cdots \mathrm{O}(8)^{\mathrm{iv}}$ & $2.686(3)$ & $172(4)$ \\
\hline $\mathrm{O}(5 \mathrm{~W})-\mathrm{H}(3 \mathrm{~B}) \cdots \mathrm{O}(6 \mathrm{~W})^{\mathrm{v}}$ & $2.903(4)$ & $147(3)$ \\
\hline $\mathrm{O}(6 \mathrm{~W})-\mathrm{H}(3 \mathrm{~B}) \cdots \mathrm{O}(7)^{\mathrm{vi}}$ & $2.916(3)$ & $162(3)$ \\
\hline $\mathrm{O}(6 \mathrm{~W})-\mathrm{H}(3 \mathrm{~B}) \cdots \mathrm{O}(8)^{\mathrm{vii}}$ & $2.893(3)$ & $175(4)$ \\
\hline \multicolumn{3}{|c|}{$\begin{array}{l}{ }^{a} \text { Symmetry transformations used to generate equivalent } \\
\text { atoms: (i) } 1 / 2-x,-1 / 2+y, 1-z \text {; (ii) } 1 / 2-x, 1 / 2+y, 2-z \text {; (iii) } \\
x,-1+y, z \text {; (iv) } 1 / 2+x, 1 / 2-y, z \text {; (v) }-1 / 2+x, 1 / 2-y, z \text {; (vi) } 1+x, y, z \text {; } \\
\text { (vii) } 1 / 2-x,-1 / 2+y, 2-z \text {. }\end{array}$} \\
\hline
\end{tabular}

It is noteworthy to mention that a previous report of this material has been recently published by Harrowfield and collaborators ${ }^{(7)}$ during their investigations of novel materials to be used as precursors for the isolation of lanthanide/transition metals mixed oxides. Since in that paper the structural features of this material were not described in the context of the Crystal Engineering of MOFs, we have redetermined its crystal structure and summarize in the following paragraphs the most relevant aspects which are of considerable importance for the theoretical studies performed and here described. A search in the literature and in the

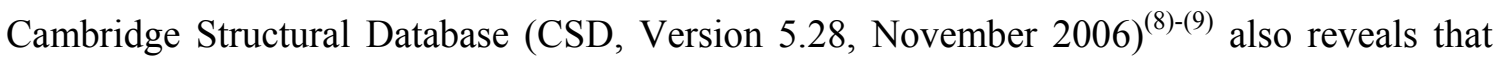
$\mathrm{H}_{2}$ DPA has been widely employed in the isolation of multi-dimensional MOF materials ${ }^{(10)-(23)}$.

The supramolecular structure of $\left[\mathrm{Eu}(\mathrm{DPA})(\mathrm{HDPA})\left(\mathrm{H}_{2} \mathrm{O}\right)_{2}\right] \cdot 4 \mathrm{H}_{2} \mathrm{O}$ is essentially mediated by the extensive hydrogen bonding network involving the various types of water molecules present in the structure. The coordinated water molecule $\mathrm{O}(1 \mathrm{~W})$ acts as a bifurcated donor promoting, on the one hand, structural cohesion of the $\infty_{\infty}^{1}\left[\mathrm{Eu}(\mathrm{DPA})(\mathrm{HDPA})\left(\mathrm{H}_{2} \mathrm{O}\right)_{2}\right]$ coordination polymer via the $\mathrm{O}(1 \mathrm{~W})-\mathrm{H}(1 \mathrm{~B}) \cdots \mathrm{O} 6$ interaction with a neighboring coordinated $\mathrm{PDA}^{2-}$ residue and, on the other, it establishes a hydrogen bonding bridge with an adjacent polymer by donating the H(1A) hydrogen to the HPDA ${ }^{-}$(Figure S1a and Table S2 for details on the hydrogen bonding geometry). These recursive supramolecular interactions along the 
[100] direction of the unit cell lead to the formation of a bilayer arrangement of $\infty_{\infty}^{1}\left[\mathrm{Eu}(\mathrm{DPA})(\mathrm{HDPA})\left(\mathrm{H}_{2} \mathrm{O}\right)_{2}\right]$ coordination polymers as depicted in Figure $\mathrm{S} 1 \mathrm{~b}$.

(a)

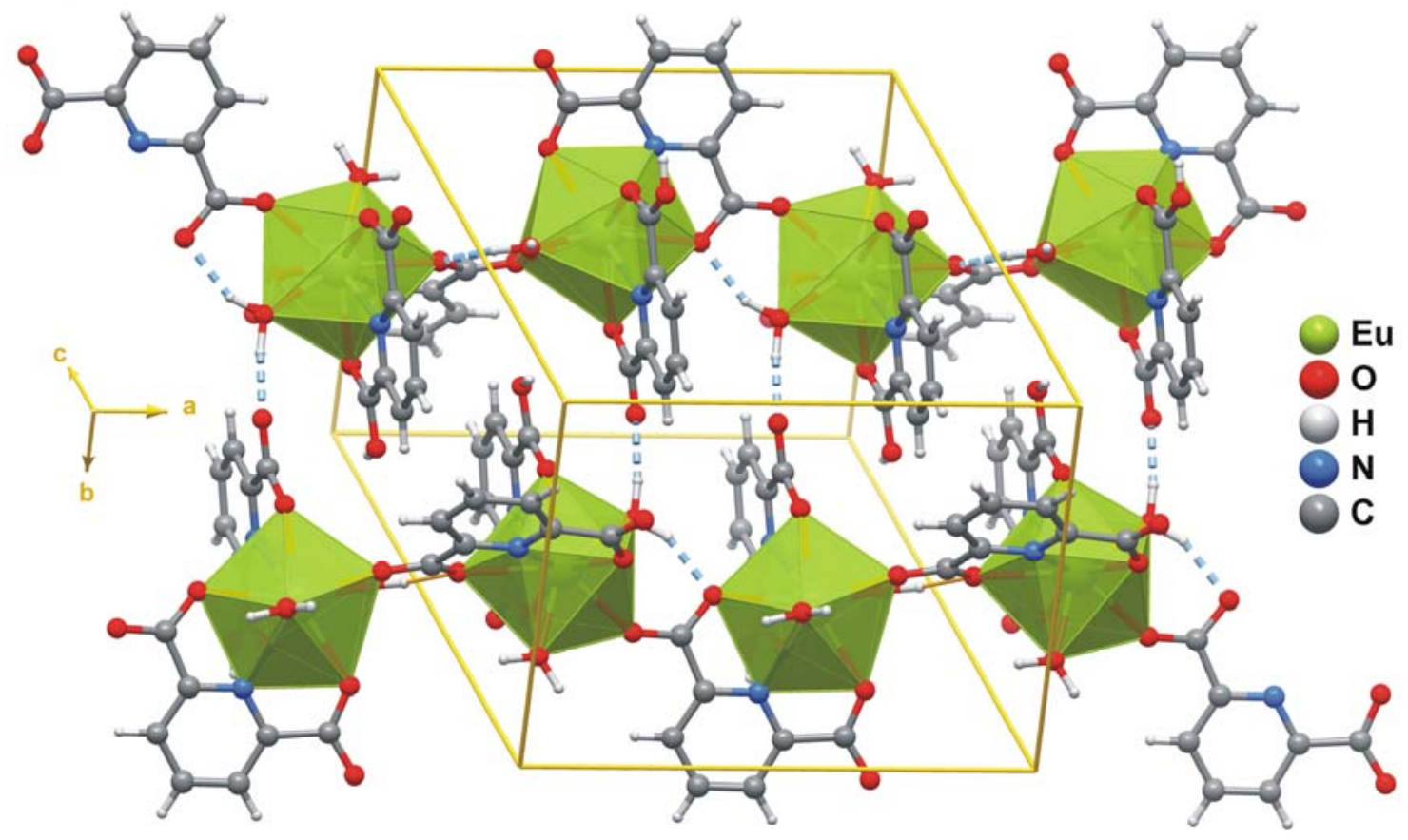

(b)

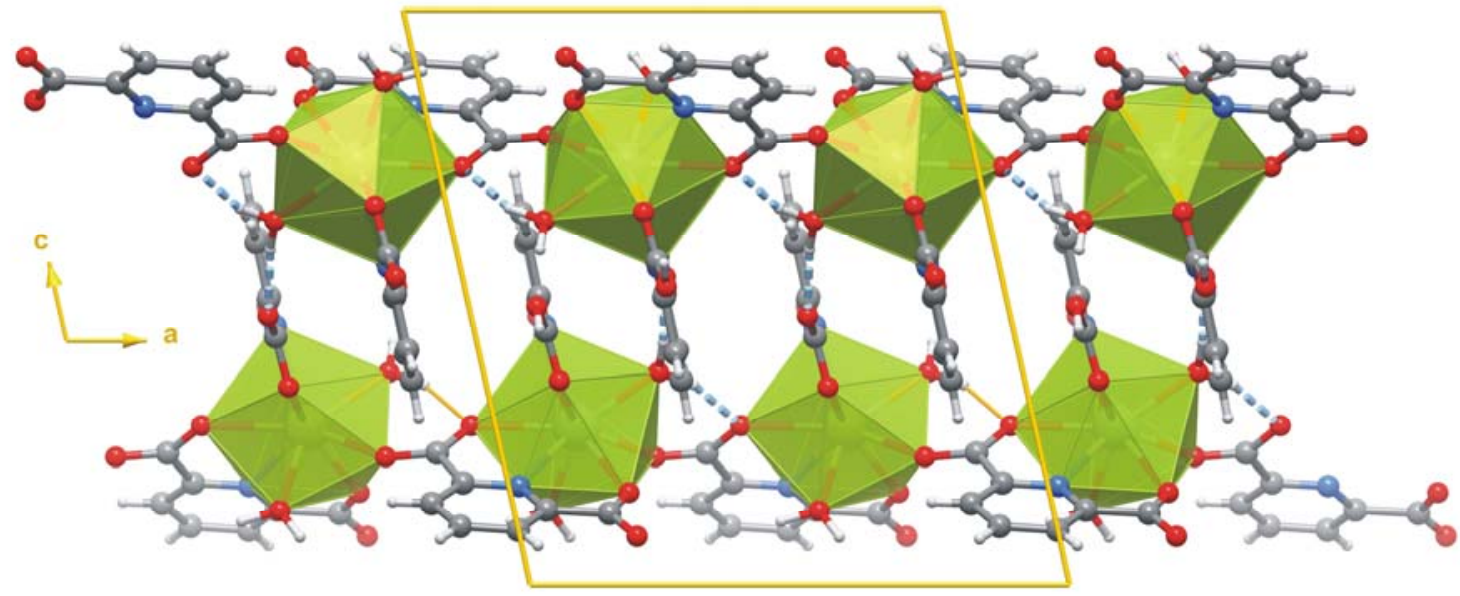

Figure S1 - (a) Schematic representation of the hydrogen bonding interactions establishing physical links between neighboring $\infty_{\infty}^{1}\left[\mathrm{Eu}(\mathrm{DPA})(\mathrm{HDPA})\left(\mathrm{H}_{2} \mathrm{O}\right)_{2}\right]$ coordination polymers and which lead to (b) bilayers placed in the $a b$ crystallographic plane. Hydrogen bonds are represented as ligh-blue dashed lines. 
Another interesting structural feature of the compound in study resides in the fact that supramolecular connections along the [001] crystallographic direction between adjacent bilayers of polymers are remarkably assured by a typical centrosymmetric hexameric water cluster involving the coordinated water molecule $\mathrm{O}(2 \mathrm{~W})$ plus another two solvent molecules housed within the interlayer space $[\mathrm{O}(5 \mathrm{~W})$ and $\mathrm{O}(6 \mathrm{~W})]$ (see Figure $\mathrm{S} 2$ and Table S2 for details on the hydrogen bonding geometry of each individual interaction). This cluster, characterized by a graph set motif of $R_{2}^{6}(12)$, exhibits a chair-like configuration with a very much identical to that commonly found in a number of compounds reported in the literature and also in $I_{h}$ ice.

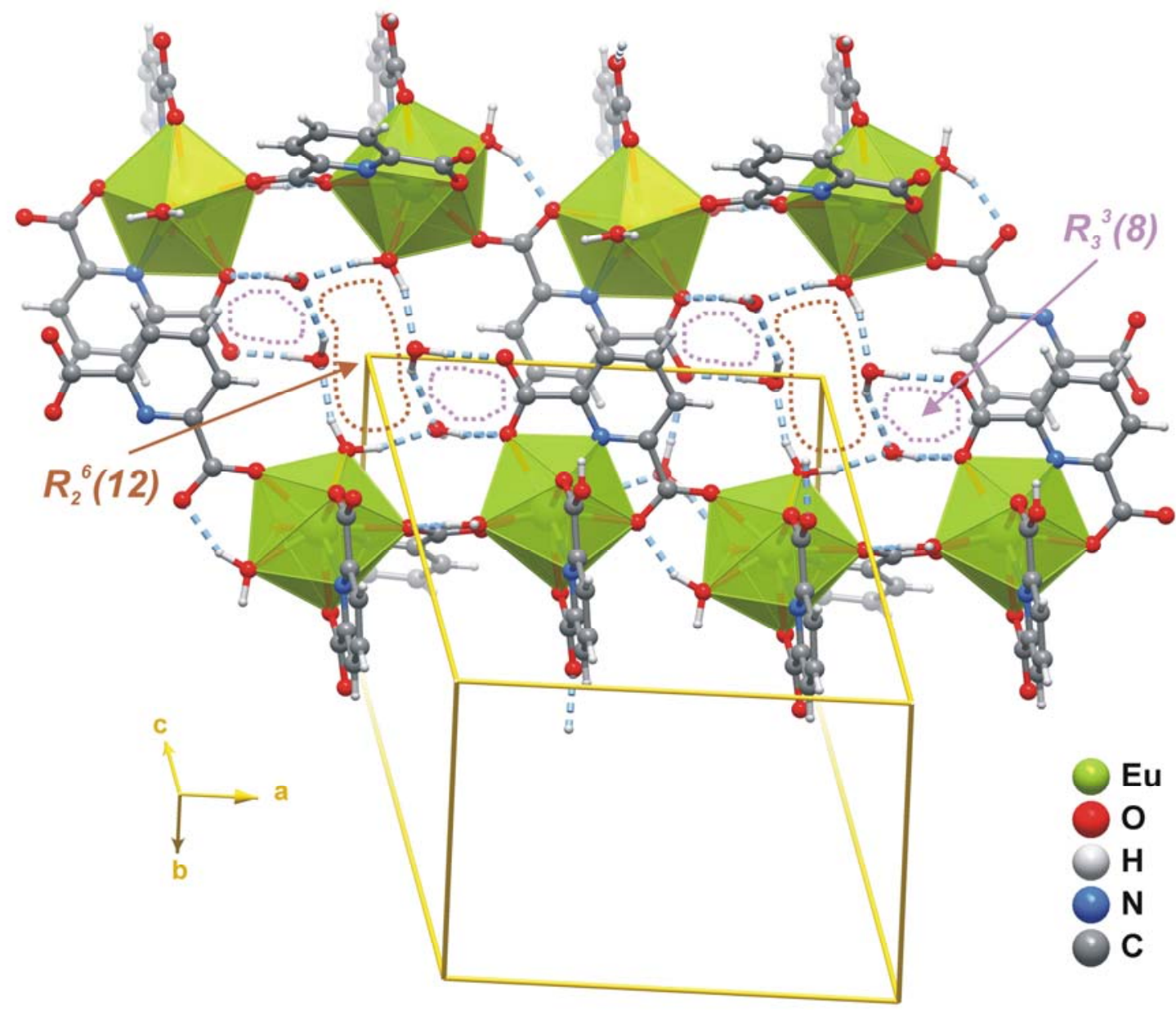

Figure S2 -Schematic representation of the centrosymmetric hexameric water clusters [composed by the $\mathrm{O}(2 \mathrm{~W})$ coordinated water molecule plus $\mathrm{O}(5 \mathrm{~W})$ and $\mathrm{O}(6 \mathrm{~W})$ located in the interlayer space] interconnecting neighboring $\infty^{1}\left[\mathrm{Eu}(\mathrm{DPA})(\mathrm{HDPA})\left(\mathrm{H}_{2} \mathrm{O}\right)_{2}\right]$ coordination polymers via a recursive $R_{2}{ }^{6}(12)$ decorated by two identical $R_{3}{ }^{3}(8)$ graph set motifs. Hydrogen bonds are represented as ligh-blue dashed lines. For geometrical details on the hydrogen bonds see Table S2. 


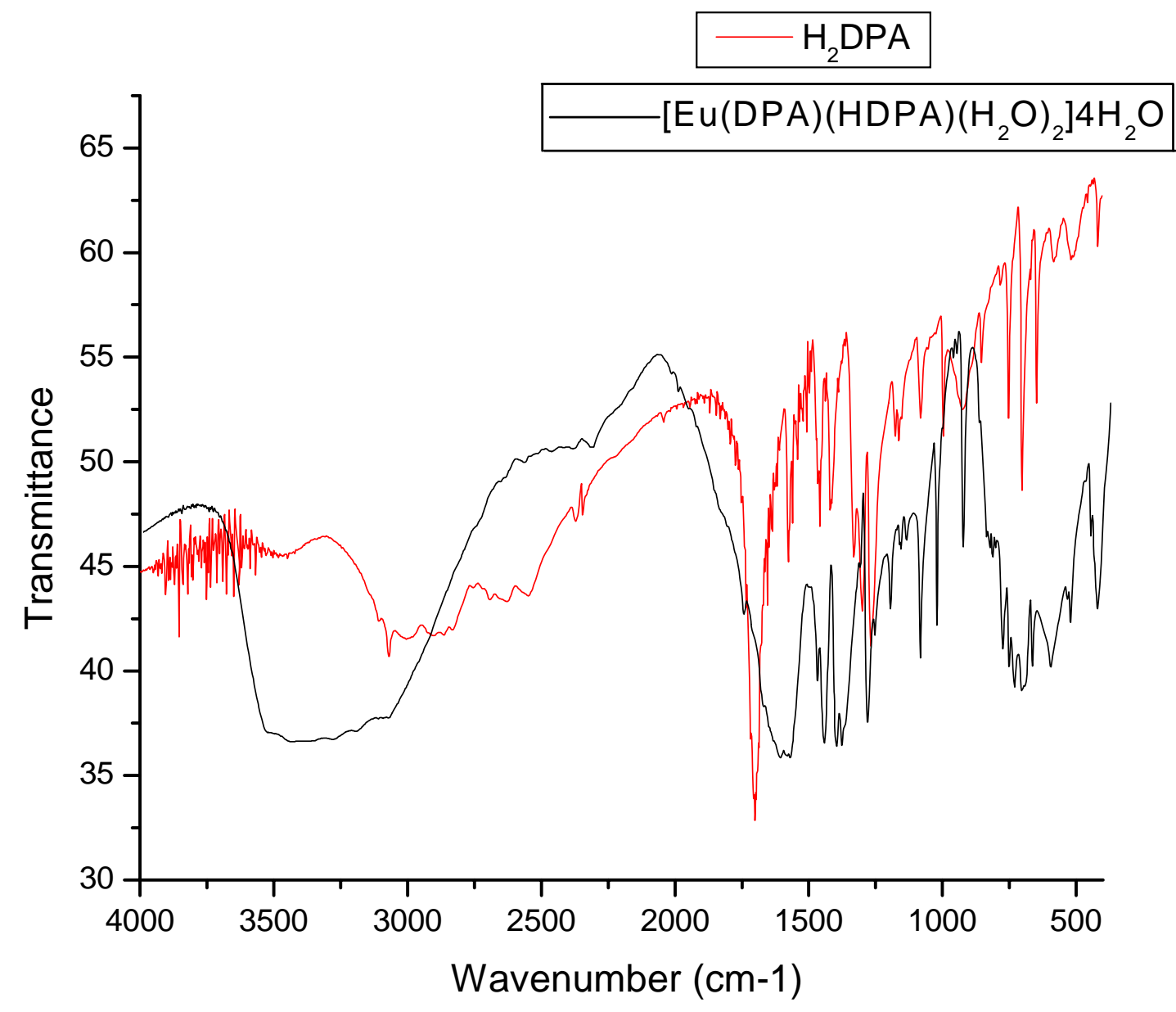

Figure S3: Comparison of the FTIR spectrums between the compounds $\left[\mathrm{Eu}(\mathrm{DPA})(\mathrm{HDPA})\left(\mathrm{H}_{2} \mathrm{O}\right)_{2}\right] \cdot 4 \mathrm{H}_{2} \mathrm{O}$ and $\mathrm{H}_{2} \mathrm{DPA}$ at $300 \mathrm{~K}$. 


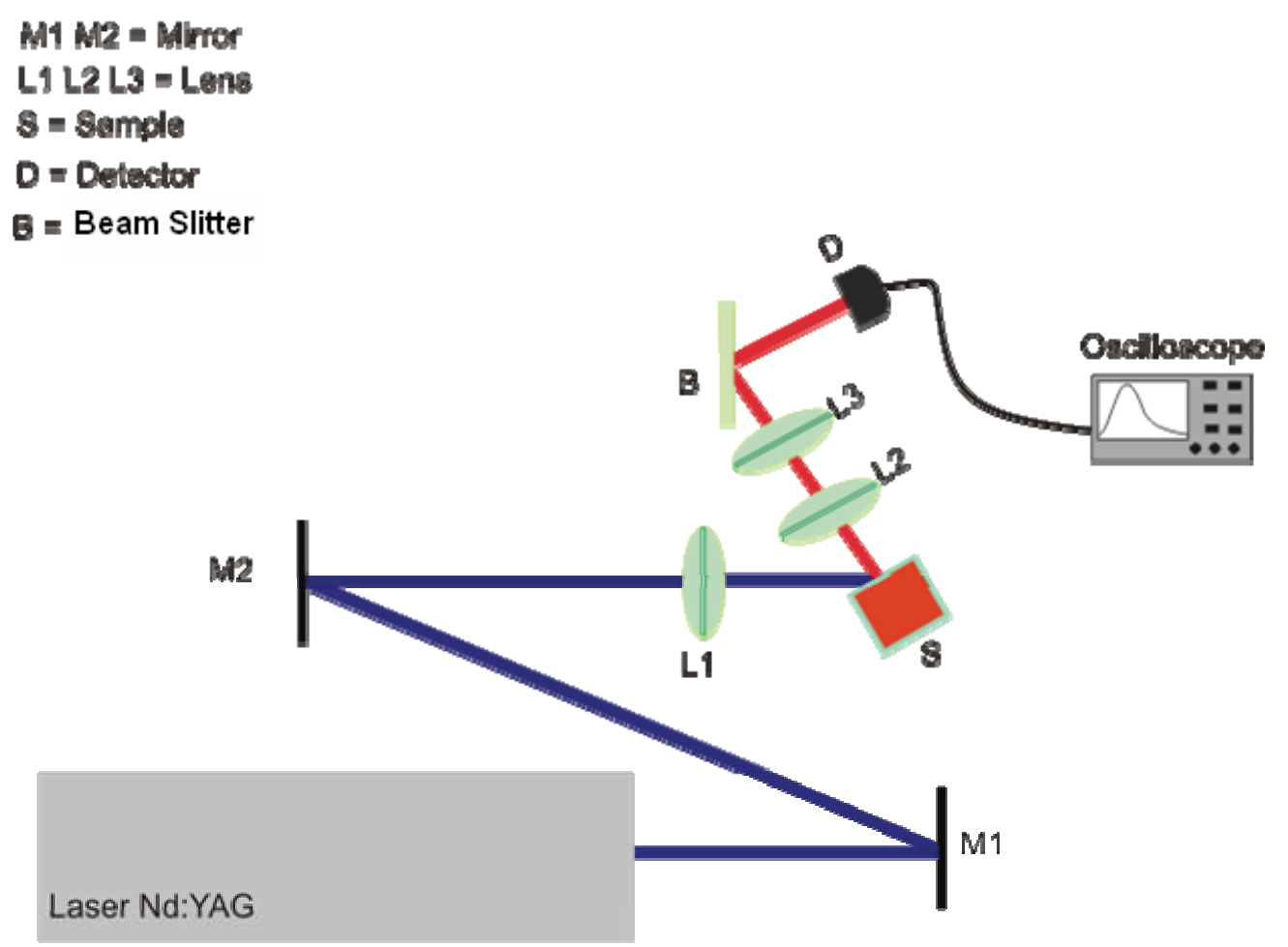

Figure S4. The experimental arrangement used to lifetime measurement of [Eu(DPA)(HDPA) $\left.\left(\mathrm{H}_{2} \mathrm{O}\right)_{2}\right] .4 \mathrm{H}_{2} \mathrm{O}$ complex. 


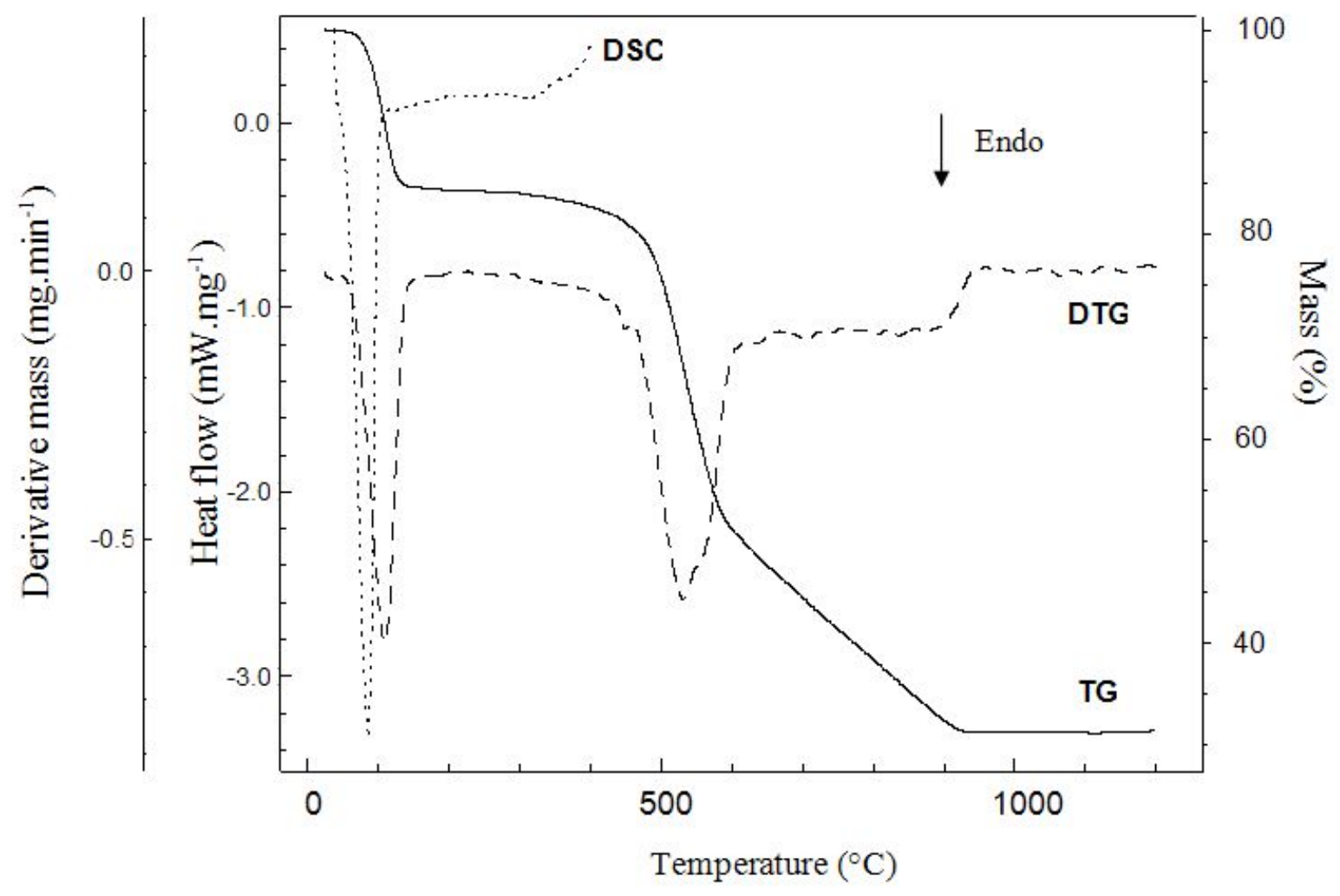

Figure S5: TG/DTG curves recorded in dynamic nitrogen atmosphere $\left(50 \mathrm{ml} \cdot \mathrm{min}^{-1}\right)$, and heating rate $10^{\circ} \mathrm{C} \cdot \mathrm{min}^{-1}$ 


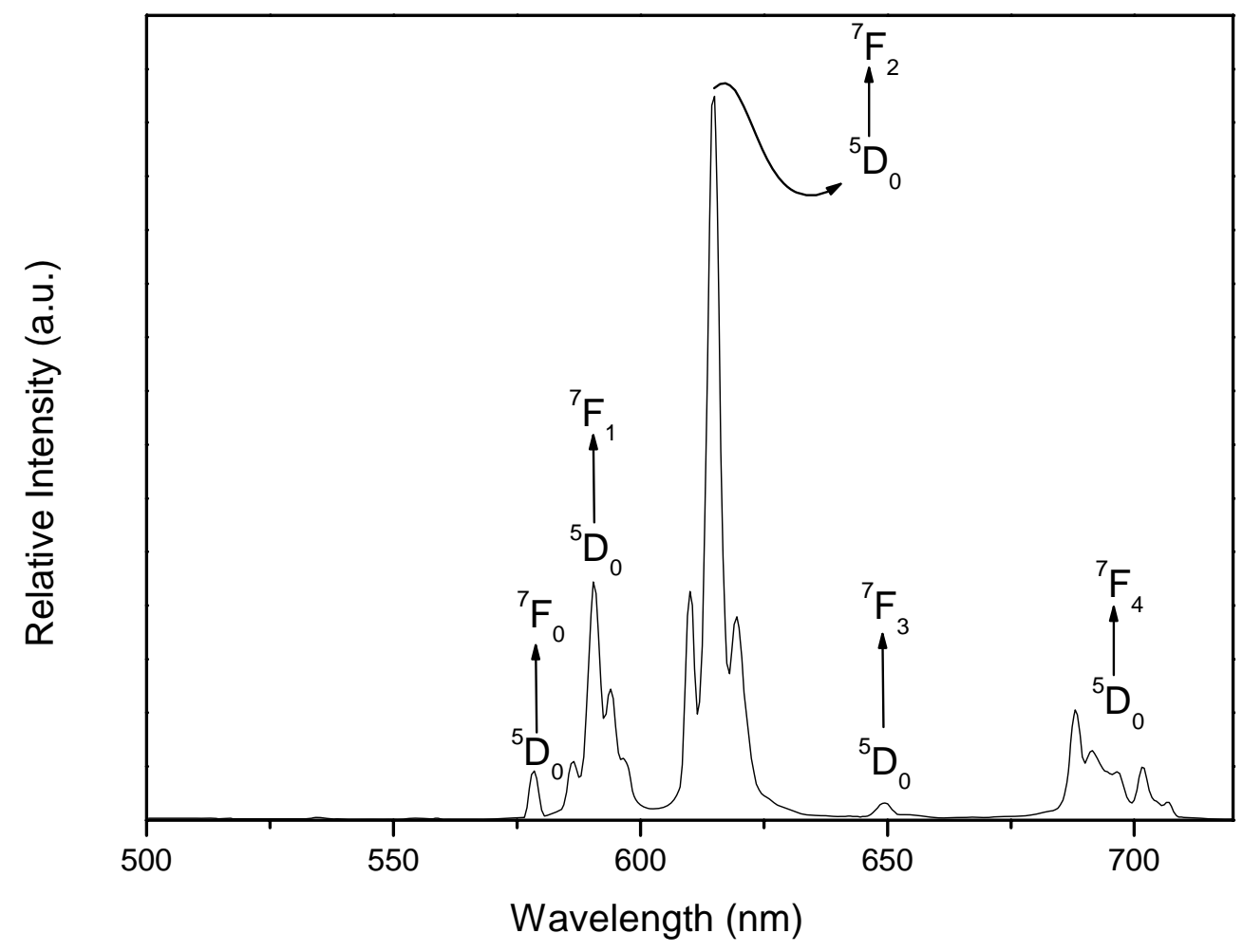

Figure S6- Emission spectra of $\left[\mathrm{Eu}(\mathrm{DPA})(\mathrm{HDPA})\left(\mathrm{H}_{2} \mathrm{O}\right)_{2}\right] \cdot 4 \mathrm{H}_{2} \mathrm{O}$ recorded at $300 \mathrm{~K}$ by monitoring excitation of ligand at $280 \mathrm{~nm}$. 


\section{References}

(1) Kottke, T.; Stalke, D. J. App. Cryst. 1993, 26, 615-619.

(2) Hooft, R. Collect: Data Collection Software, Delft, The Netherlands, Nonius B. V. 1998.

(3) Otwinowski, Z.; Minor, W., In Methods in Enzymology, Carter Jr., C. W.; Sweet, R. M., Eds. Academic Press: New York, 1997; Vol. 276, p 307.

(4) Sheldrick, G. M. SADABS v.2.01, Bruker/Siemens Area Detector Absorption Correction Program 1998, Bruker AXS, Madison, Wisconsin, USA.

(5) Sheldrick, G. M. SHELXS-97, Program for Crystal Structure Solution, University of Göttingen 1997.

(6) Sheldrick, G. M. SHELXL-97, Program for Crystal Structure Refinement, University of Göttingen 1997.

(7) Brayshaw, P. A.; Hall, A. K.; Harrison, W. T. A.; Harrowfield, J. M.; Pearce, D.; Shand, T. M.; Skelton, B. W.; Whitaker, C. R.; White, A. H. Eur. J. Inorg. Chem. 2005, 1127 1141.

(8) Allen, F. H. Acta Cryst. B 2002, 58, 380-388.

(9) Allen, F. H.; Motherwell, W. D. S. Acta Cryst. B 2002, 58, 407-422.

(10) Ramezanipour, F.; Aghabozorg, H.; Shokrollahi, A.; Shamsipur, M.; Stoeckli-Evans, H.; Soleimannejad, J.; Sheshmani, S. J. Mol. Struct. 2005, 779, 77-86.

(11) Prasad, T. K.; Rajasekharan, M. V. Inorg. Chem. Commun. 2005, 8, 1116-1119.

(12) Prasad, T. K.; Sailaja, S.; Rajasekharan, M. V. Polyhedron 2005, 24, 1487-1496.

(13) Liu, S. H.; Li, Y. Z.; Meng, Q. J. Acta Cryst. E 2005, 61, M1111-M1113.

(14) Zhao, B.; Yi, L.; Dai, Y.; Chen, X. Y.; Cheng, P.; Liao, D. Z.; Yan, S. P.; Jiang, Z. H. Inorg. Chem. 2005, 44, 911-920.

(15) Ghosh, S. K.; Bharadwaj, P. K. Inorg. Chem. 2004, 43, 2293-2298.

(16) Duan, L. Y.; Li, Y. G.; Liu, F. C.; Wang, E. B.; Wang, X. L.; Hu, C. W.; Xu, L. J. Mol. Struct. 2004, 689, 269-274.

(17) Ghosh, S. K.; Bharadwaj, P. K. Inorg. Chem. 2003, 42, 8250-8254.

(18) Brouca-Cabarrecq, C.; Fernandes, A.; Jaud, J.; Costes, J. P. Inorg. Chim. Acta 2002, 332, 54-60.

(19) Sailaja, S.; Rajasekharan, M. V. Acta Cryst. E 2001, 57, M341-M343.

(20) Fernandes, A.; Jaud, J.; Dexpert-Ghys, J.; Brouca-Cabarrecq, C. Polyhedron 2001, 20, $2385-2391$. 
(21) Rzaczynska, Z.; Brzyska, W.; Mrozek, R.; Ozga, W.; Glowiak, T. J. Coord. Chem. 1998, 43, 321-334.

(22) Swarnabala, G.; Rajasekharan, M. V. Inorg. Chem. 1998, 37, 1483-1485.

(23) Starynowicz, P. Acta Cryst. C 1992, 48, 1428-1430. 